\title{
PENGARUH MODEL PEMBELAJARAN STUDENT FACILITATOR TERHADAP KEMAMPUAN MEMBACA UNTUK SDN 98 PALEMBANG
}

\author{
Yus Vernandes Uzer, M.PD \\ Univ.PGRI Palembang \\ Email: yusfernandes@gmail.com
}

\begin{abstract}
Abstrak :Masalah dalam hasil penelitian ini adalah adakah Pengaruh Model Pembelajaran Student Facilitator terhadap Kemampuan Membaca untuk SDN 98 Palembang Tujuan penelitian ini untuk mengetahui dan mendeskripsikan Pengaruh Model Pembelajaran Student Facilitator terhadap Kemampuan Membaca untuk SDN 98 Palembang. Metode penelitian ini adalah metode eksperimen semu dengan rancangan kelas eksperimen dan kelas kontrol. Populasi penelitian ini adalah seluruh siswa kelas III di SDN 93 Palembang yang berjumlah seluruhnya 165 siswa. Sampel penelitian kelas eksperimen berjumlah 31 siswa dan kelas kontrol berjumlah 31 siswa. Teknik pengumpulan data yang digunakan dalam penelitian ini adalah teknik tes, dan dokumentasi. Teknik analisis data yang digunakan untuk membuktikan hipotesis adalah uji-t. Hasil penelitian menunjukan bahwa nilai ratarata hasil tes eksperimen yang menggunakan metode pembelajaran student facilitator dalam pembelajaran menyimpulkan isi berita adalah $74,87 \%$ lebih tinggi dibandingkan kelas kontrol yang tidak menggunakan model pembelajaran student facilitator dalam pembelajaran menyimpulkan isi berita dengan nilai rata-rata 70,96\%. Dari uji homogen, bahwa sampel yang ada diperoleh dari populasi yang homogen ini dibuktikan bahwa $F_{\text {hitung }}<F_{\text {tabel }}=2,58<1,67$. Untuk uji hipotesis diperoleh $\mathrm{t}_{\text {hitung }}=7,03$ pada taraf signifikan $0,05(5 \%)$ dengan db 60 yaitu 2,00 sehingga $\mathrm{t}_{\text {tabel }}<\mathrm{t}_{\text {hitung }}$

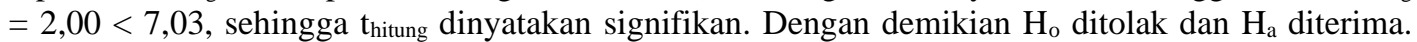
Berdasarkan pernyataan tersebut dapat diketahui bahwa terdapat pengaruh yang signifikan Model Pembelajaran Student Facilitator terhadap Kemampuan Membaca untuk SDN 98 Palembang.

Kata Kunci: Pengaruh, Model Pembelajaran Student Facilitator, Kemampuan Membaca
\end{abstract}

\section{PENDAHULUAN}

Berbagai cara dapat dilakukan guru dalam melaksanakan pembelajaran bahasa Indonesia disekolah, termasuk kemampuan menyimpulkan isi berita. salah satunya dengan menggunakan model pembelajaran tertentu yang bertujuan meningkatkan minat siswa dalam mengikuti pembelajaran sehingga dapat meningkatkan kemampuan berbahasa siswa yang pada akhirnya mampu memperoleh hasil belajar yang maksimal.
Model pembelajaran merupakan suatu rencana atau pola yang dapat digunakan untuk membentuk kurikulum (rencana pembelajaran jangka panjang), merancang bahanbahan pembelajaran, dan membimbing pembelajaran dikelas atau yang lain (Joyce \& Weil dikutip Rusman, 2012:133). Melalui penggunaan model pembelajaran tersebut, maka pelaksanaan pembelajaran dapat direncanakan secara sistematis untuk mencapai tujuan pembelajaran yang ingin 
dicapai melalui pembelajaran itu sendiri.

Salah satu model pembelajaran yang dapat digunakan guru dalam meningkatkan kemampuan berbahasa siswa, khususnya kemampuan menyimpulkan isi berita kriminal yang dibacakan dalam beberapa kalimat adalah model pembelajaran student facilitator.Menurut Huda (2014:228) model pembelajaran student facilitator merupakan rangkaian penyajian materi ajar yang diawali dengan penjelasan secara terbuka, memberi kesempatan siswa untuk menjelaskan kembali kepada rekan-rekannya, dan diakhiri dengan penyampaian semua materi kepada siswa. Penerapan model pembelajaran student facilitator yang telah dipersiapkan berdasarkan materi yang sedang dibahas, yaitu menyimpulkan isi berita. Berita adalah kejadian yang diulang dengan menggunakan katakata, sering juga ditambah dengan gambar atau hanya berupa gambargambar saja (Siregar dikutip Chaer, 2010:11).

Berdasarkan hasil observasi awal diketahui bahwa kemampuan siswa kelas III SDN 93 Palembang pada mata pelajaran Bahasa
Indonesia, aspek mendengarkan masih dikategorikan rendah. Siswa kurang mampu menunjukkan pokokpokok berita, menunjukkan isi berita, dan menyimpulkan isi berita. Ratarata hasil ulangan siswa masih tergolong rendah dan belum mencapai standar ketuntasan, khususnya pada materi pembelajaran menyimpulkan isi berita. Oleh karena itu peneliti akan melakukan penelitian dengan judul "Pengaruh Model Pembelajaran Student Facilitator terhadap Kemampuan Membaca untuk SDN 98 Palembang".

Masalah merupakan sesuatu yang harus dipecahkan, agar masalah yang diteliti lebih terarah dan dapat menuju sasaran pelaksanaan penelitian, maka diberikan pembatasan, yaitu:

1) Pengaruh yang dimaksud dalam penelitian ini adalah pengaruh model pembelajaran student facilitator dalam meningkatkan hasil belajar siswa.

2) Hasil belajar yang dimaksud adalah hasil belajar setelah diterapkannya model pembelajaran student facilitator pada materi menyimpulkan isi berita, khususnya berita kriminal. 
Berdasarkan latar belakang yang telah diuraikan di atas, maka masalah dalam penelitian ini adalah adakah Pengaruh Model Pembelajaran Student Facilitator terhadap Kemampuan Membaca untuk SDN 98 Palembang?

\section{LANDASAN TEORI}

\subsection{Pengertian Model Pembelajaran}

Istilah yang umumnya dikenal dalam kegiatan belajar mengajar adalah pendekatan, model pembelajaran, strategi pembelajaran, metode pembelajaran, teknik pembelajaran dan keterampilan mengajar. Sebelum membahas tentang model pembelajaran, terlebih dahulu kita akan mengkaji apa itu model? Secara kaffah model dimaknai sebagai suatu objek atau konsep yang digunakan untuk merepresentasikan suatu hal. Joyce \& Weil (dikutip Rusman, 2012:133) menyatakan bahwa, "model pembelajaran adalah suatu rencana atau pola yang dapat digunakan untuk membentuk kurikulum (rencana pembelajaran jangka panjang), merancang bahanbahan pembelajaran, dan membimbing pembelajaran dikelas atau yang lain." Menurut Joyce (dikutip Trianto, 2013:22) model pembelajaran adalah suatu perencanaann atau suatu pola yang digunakan sebagai pedoman dalam merencanakan pembelajaran di kelas atau pembelajaran dalam tutorial dan untuk menentukan perangkatperangkat pembelajaran termasuk didalamnya buku-buku, film, komputer, kurikulum dan lain-lain.

Ciri utama sebuah model pembelajaran adalah adanya tahap atau sintaks pembelajaran. Dari pengertian para ahli diatas peneliti menyimpulkan bahwa model pembelajaran adalah suatu upaya untuk membentuk rencana pembelajaran yang mencakup fasilitas belajar di kelas.

\subsection{Pengertian Model Pembelajaran Student Facilitator}

Menurut Huda (2014:228), model pembelajaran student facilitator merupakan rangkaian penyajian materi ajar yang diawali dengan penjelasan secara terbuka, memberi kesempatan siswa untuk menjelaskan kembali kepada rekanrekannya, dan diakhiri dengan penyampaian semua materi kepada siswa. Menurut Burden dan Byrd (dikutip Sutriyani, 2013:7), menyatakan bahwa model 
pembelajaran student facilitator

adalah suatu kerangka pembelajaran yang mengikut sertakan siswa untuk membantu teman-temannya dalam belajar.

Dari pendapat diatas dapat disimpulkan bahwa model pembelajaran student facilitator adalah model pembelajaran dimana siswa belajar mempersentasikan hasil belajarnya dikelas kepada temanteman sekelasnya. Model pembelajaran ini dilakukan dengan belajar bersama antar siswa atau sesama siswa. Model pembelajaran student facilitator adalah proses pembelajaran yang melibatkan siswa untuk membantu teman-temannya untuk memahami materi pembelajaran yang sedang dipelajari.

\subsection{Langkah-Langkah Pembelajaran Student Facilitator}

Menurut Huda (2014:228-229), langkah-langkah pembelajaran student facilitator adalah sebagai berikut.

a) Guru menyampaikan kompetisi yang dicapai.

b) Guru mendemostrasikan atau menyajikan garis-garis besar materi pembelajaran. c) Guru memberi kesempatan kepada siswa untuk menjelaskan kepada siswa lainnya, misalnya melalui bagan atau peta konsep.

d) Guru menyimpulkan ide atau pendapat siswa.

e) Guru menerangkan semua materi yang disajikan saat itu.

f) Penutup.

\subsection{Pengertian Berita}

"Berita adalah kejadian yang diulang dengan menggunakan katakata, sering juga ditambah dengan gambar atau hanya berupa gambargambar saja" (Siregar dikutip Chaer, 2010:11). Menurut Turner Catledge (dikutip Latuconsina, 2014:29) berita adalah segala sesuatu yang tidak anda ketahui pada hari kemarin. Berita juga dapat diartikan sebagai segala sesuatu yang dianggap sebagai berita oleh redaksi.

Dari pendapat di atas, peneliti dapat menyimpulkan bahwa berita ialah kejadian dimana terjadi peristiwa atau kabar yang kemudian menjadi sebuah cerita atau informasi.

Menurut Chaer (2010:20 mengatakan bahwa, ada beberapa struktur yang membangun teks berita. Struktur teks tersebut merupakan struktur yang membangun teks 
sehingga menjadi satu kesatuan yang utuh. Struktur berita terdiri atas judul, teras berita dan tubuh berita.

a) Judul Berita

Judul berita, disebut juga kepala berita. judul berita merupakan kata kunci yang mewakili keseluruhan berita. Pada teks berita , judul biasanya memuat tentang apa kejadian yang dibahas atau disampaikan. Judul berita harus dibuat sedemikian rupa sehingga tampak menarik dan "hidup".

b) Teras Berita

Teras berita adalah bagian yang penting dari sebuah berita, yang ditempatkan pada paragraf pertama dibawah judul berita.

c) Badan Berita

Badan berita merupakan penjabaran atau perincian yang lebih luas tentang teras berita.

Menurut Chaer, (2010:17), setiap berita baik yang bersifat langsung, berita ringan maupun berita harus berisi fakta-fakta yang menyangkut manusia, meskipun yang diceritakan hewan atau benda-benda yang terdapat di dalam masyarakat. semua berita itu harus mengungkapkan unsur $5 \mathrm{~W}$ dan $1 \mathrm{H}$, yaitu. a) Unsur what (apa yang terjadi)

Berkenaan dengan fakta-fakta yang berkaitan dengan hal-hal yang dilakukan oleh pelaku ataupun korban dari kejadian itu. Hal yang dilakukan dapat berupa penyebab kejadian, tetapi dapat pula berupa akibat kejadian.

b) Unsur who (siapa yang terlibat dalam kejadian)

Berkenaan dengan fakta-fakta yang berkaitan dengan orang atau pelaku yang terlibat dalam kejadian itu. Orang yang diberitakan harus bisa diidentifikasikan namanya, umurnya, pekerjaannya, dan berbagai keterangan mengenai orang tersebut.

c) Unsur why (mengapa kejadian itu timbul)

Berkenaan dengan fakta-fakta yang berkaitan dengan latar belakang dari suatu tindakan ataupun suatu kejadian yang telah diketahui unsur what-nya.

d) Unsur where (dimana tempat kejadian itu)

Berkenaan dengan tempat peristiwa terjadi. Disini nama tempat harus diidentifikasikan dengan jelas. Ciri-ciri tempat 
kejadian merupakan hal yang penting untuk diberitakan.

e) Unsur when (kapan terjadinya) Berkaitan dengan waktu kejadian.

f) Unsur how (bagaimana kejadiannya)

Berkenaan dengan proses kejadian yang diberitakan. Misalnya, bagaimana terjadinya suatu peristiwa, bagaimana pelaku melakukan perbuatanya, atau bagaimana korban mengalami nasibnya.

\subsection{Langkah-Langkah} Menyimpulkan Isi Berita

Langkah-langkah menyimpulkan isi berita sebagai berikut:

a) Siapkan alat tulis untuk mencatat hal-hal penting berita yang didengar.

b) Mulailah mendengarkan berita yang diperdengarkan dengan penuh konsentrasi.

c) Catatlah hal-hal penting yang berpedoman pada unsur $5 \mathrm{~W}+1 \mathrm{H}$.

d) Berdasarkan catatan hal-hal penting tadi, rangkailah ke dalam sebuah paragraf simpulan isi berita.

\section{METODOLOGI PENELITIAN}

\subsection{Metode Penelitian}

Metode penelitian adalah cara yang digunakan oleh peneliti dalam mengumpulkan data penelitiannya (Arikunto, 2013:203). Penelitian ini menggunakan metode eksperimen semu. Metode eksperimen semu adalah metode penelitian yang hanya menilai hasil post test atau membandingkan hasil tes akhir.

Metode eksperimen dalam penelitian ini, satu kelas sebagai kelas eksperimen yang dikenakan perlakuan (diajarkan dengan mengunakan model student facilitator) dan satu kelas sebagai kelas kontrol yang tidak dikenakan perlakuan (tidak diajarkan dengan mengunakan model student facilitator), lalu kedua kelas tersebut dikenakan pengukuran yang sama.

\subsection{Populasi dan Sampel}

Menurut Sugiyono (2012:80), populasi adalah wilayah generalisasi yang terdiri atas obyek/subyek yang mempunyai kualitas dan karateristik tertentu yang ditetapkan oleh peneliti untuk dipelajari dan kemudian ditarik kesimpulan.

Berdasarkan pendapat di atas maka yang menjadi populasi dalam 
penelitian ini adalah seluruh siswa kelas III SDN 98 Palembang,

$$
\text { Arikunto }
$$

(2013:174)

mengemukakan "sampel adalah sebagian atau wakil populasi yang diteliti." Sampel dalam penelitian ini adalah sebagian siswa kelas VII SMP Sriguna Palembang.

Teknik pengambilan sampel pada penelitian ini menggunakan random sampling (acak), sehingga diperoleh kelas III.1 sebagai kelas eksperimen yang diajarkan menggunakan model pembelajaran student facilitator dan kelas III.2 sebagai kelas kontrol yang tidak diajarkan menggunakan model pembelajaran student facilitator.

\subsection{Teknik Pengumpulan Data}

Teknik pengumpulan data merupakan langkah yang paling strategis dalam penelitian, karena tujuan utama dari penelitian adalah mendapatkan data. Tanpa mengetahui teknik pengumpulan data, maka penelitih tidak akan mendapatkan data yang memenuhi standar data yang ditetapkan (Sugiyono, 2012:224). Penelitian ini menggunakan teknik tes dan dokumentasi.

\subsection{Teknik Analisis Data}

Setelah data terkumpul dari hasil pengumpulan data, perlu segera digarap oleh peneliti. Teknik analisis data tes dalam penelitian ini menggunakan uji normalitas data, homogenitas data dan pengujian hipotesis. Untuk lebih jelasnya ketiga penguji tersebut diuraikan sebagai berikut.

Uji normalitas data digunakan untuk mengetahui apakah data berdistribusi normal atau tidak. Uji normalitas dilakukan sebagai bahan petimbangan yang digunakan untuk menguji normalitas data, maka diperlukan daftar distribusi frekuensi dengan langkah-langkah sebagai berikut.

1) Rentang = data terbesar - data terkecil

2) Banyak kelas $=1+3,3 \log (n)$

3) Menentukan panjang interval $(\mathrm{P})=\frac{\text { rentang }}{\text { banyak kelas }}$

4) Membuat tabel frekuensi

5) Mencari rata-rata

$\mathrm{x}=\sum \frac{\text { fixi }}{f i}$ (Sudjana, 2013:67)

Keterangan :

$x=$ Rata-Rata

$x_{i}=$ Tanda-Tanda Interval 
$f_{i}=$ Frekuensi yang sesuai dengan tanda kelas interval

6) Mencari modus dengan rumus sebagai berikut.

$\mathrm{M}_{\mathrm{O}}=\mathrm{b}+\mathrm{p}\left\{\frac{b 1}{b_{1}+b_{2}}\right\} \quad$ (Sudjana, 2013:77)

Keterangan:

Mo $=$ Modus

B = Batas bawah kelas modal, yaitu kelas interval dengan frekuensi terbanyak.

$\mathrm{P}=$ Panjang kelas interval

$\mathrm{b}_{1}=$ Frekuensi kelas modus dikurangi frekuensi kelas sebelumnya.

$\mathrm{b}_{2}=$ Frekuensi kelas modus dikurangi frekuensi kelas berikutnya.

7) Mencari simpangan baku/standar deviasi

$\left(s^{2}\right)=\frac{n\left(\sum f i x i^{2}\right)-\left(\sum f i x i\right)^{2}}{n(n-1)} \quad($ Sudjana, 2013:95)

Keterangan:

$S^{2} \quad=$ Simpangan baku

$x_{i} \quad=$ Tanda kelas interval

$f_{i} \quad=$ Frekuensi yang sesuai dengan kelas interval

$n$ = banyak kelas

8) Memasukkan (modus, rata-rata, dan standar deviasi) kelas dalam rumus koefisien person. Untuk menguji apakah data tersebut berdistribusi normal, maka digunakan uji kemiringan kurva dengan rumus sebagai berikut.

$K_{\mathrm{m}}=\frac{\bar{x}-M_{O}}{S} \quad$ (Sudjana, 2013:109)

Keterangan:

$\mathrm{Km}=$ Kemiringan kurva

$\bar{x} \quad=$ Nilai rata-rata

$M_{o} \quad=$ Modus

$S \quad=$ Standar deviasi

Kriteria nilai $\mathrm{Km}$ terletak antara (-1) dan (+1) maka data tersebut berdistribusi normal.

Uji homogenitas data perlu ini peneliti menggunakan uji Barlett dilakukan untuk membuktikan dengan langkah-langkah sebagai persamaan varians kelompok yang berikut:

membentuk sampel, dengan kata lain kelompok yang diambil berasal dari populasi yang sama. Dalam penelitian

1) Mencari nilai varians terbesar dan varians terkecil dengan rumus:

$$
F_{\text {hitung }}=\frac{\text { Varian terbesat }}{\text { Varian terkecil }}
$$

2) Membandingkan nilai $F_{\text {hitung }}$ dengan $F_{\text {tabel. }}$

Dengan rumus:

$\mathrm{dk}$ pembilang $=\mathrm{n}-1$ (untuk varians terbesar) $\mathrm{dk}$ penyebut $=\mathrm{n}-1$ (untuk varians terkecil) 
Taraf signifikan $(\alpha)=0,05$ maka dicari tabel $F$ didapat $F_{\text {tabel }}=1,67$.

3) Kriteria pengujian.

Jika : $F_{\text {hitung }} \geq F_{\text {tabel }}$, berarti tidak homogen.

Jika : $F_{\text {hitung }} \leq F_{\text {tabel }}$, berarti homogen.

Sesuai dengan tujuan penelitian, maka dalam penelitian ini data yang didapat hasil post-tes. Data ini akan dianalisis untuk pengujian hipotesis penelitian, apakah diterima atau ditolak.

selanjutnya dilakukan uji hipotesis dengan menggunakan uji-t pada taraf signifikan $\alpha=0,05$, yaitu. normalitas dan homogenitas, maka

$$
\mathrm{t}=\frac{\bar{x}_{1}-\bar{x}_{2}}{\sqrt[s]{\frac{1}{n_{1}}+\frac{2}{n_{2}}}}
$$

Dengan

$S==\frac{\sqrt{\left(n_{1}-1\right) S_{1} 2+\left(n_{1}-1\right) S_{2} 2}}{\mathrm{n}_{1}+\mathrm{n}_{2}-2}$

Keterangan

$\mathrm{t} \quad=$ Perbandingan dua sampel

$\mathrm{n}_{1}=$ Jumlah siswa kelas eksperimen

$\mathrm{n}_{2}=$ Jumlah kelas kontrol

$\mathrm{s}=$ Simpangan baku

$\mathrm{s}_{1}{ }^{2}=$ Nilai varian kelas eksperiman

$\mathrm{s}_{2}{ }^{2}=$ Nilai varians kelas kontrol

$\bar{x}_{1}=$ Rata-rata hitung kelas eksperimen

$\bar{x}_{2}=$ Rata-rata hitung kelas kontrol

\section{PEMBAHASAN}

Dari hasil tes siswa kelas III SDN 98 Palembang dalam menulis kesimpulan isi berita dikategorikan baik. Tes diberikan oleh peneliti kepada siswa kelas eksperimen (kelas III.1) dan siswa kelas kontrol (kelas III.2). kelas eksperimen adalah kelas yang mendapat perlakuan penerapan model pembelajaran student facilitator pada materi menyimpulkan isi berita sedangkan kelas kontrol adalah kelas yang tidak mendapat perlakuan penerapan model 
pembelajaran student facilitator pada materi menyimpulkan isi berita.

Hari hasil analisis data penelitian yang telah dilakukan oleh peneliti, bahwa siswa kelas eksperimen yang menggunakan model pembelajaran student facilitator dalam pembelajaran menyimpulkan isi berita yang dibacakan dalam beberapa kalimat mendapat hasil yang baik dengan nilai rata-rata $74,87 \%$ dibandingkan dengan siswa pada kelas kontrol yang tidak menggunakan model pembelajaran student facilitator dalam pembelajaran menyimpulkan isi berita mendapat hasil cukup dengan nilai rata-rata $70,69 \%$. Hal ini diketahui dari jumlah siswa kelas eksperimen yang mencapai nilai kriteria ketuntasan minimal sebanyak 28 siswa dengan persentase $(90,32 \%)$ dan jumlah siswa yang tidak mencapai nilai kriteria ketuntasan minimal sebanyak 3 siswa dengan persentase $(9,68 \%)$ dan hasil nilai rata-rata siswa kelas eksperimen adalah $74,87 \%$. Sedangkan jumlah siswa kelas kontrol yang mencapai nilai kriteria ketuntasan minimal sebanyak 23 siswa dengan persentase $(74,20 \%)$ dan jumlah siswa yang tidak mencapai nilai kriteria ketuntasan minimal sebanyak 8 siswa dengan persentase $(25,80 \%)$ dan hasil nilai rata-rata kelas kontrol adalah $70,96 \%$.

Dari hasil uji homogen, bahwa sampel yang ada diperoleh dari populasi yang homogen ini dibuktikan bahwa $F_{\text {hitung }}<\mathrm{F}_{\text {tabel }}=$ $2,58<1,67$. Untuk uji hipotesis diperoleh $t_{\text {hitung }}=6,32$ pada taraf signifikan $0,05(5 \%)$ dengan $\mathrm{db}=60$ yaitu 2,00 sehingga $t_{\text {tabel }}<t_{\text {hitung }}=$ $2,00<6,32, \quad$ sehingga $t_{\text {hitung }}$ dinyatakan signifikan. Dengan demikian $\mathrm{H}_{0}$ ditolak dan $\mathrm{H}_{\mathrm{a}}$ diterima. Berdasarkan pernyataan tersebut dapat diketahui bahwa terdapat pengaruh yang signifikan Model Pembelajaran Student Facilitator terhadap Kemampuan Membaca untuk SDN 98 Palembang.

\section{KESIMPULAN}

Berdasarkan uraian penulis dalam bab-bab sebelumnya dapat disimpulkan bahwa rata-rata hasil tes siswa kelas eksperimen yang menggunakan model pembelajaran student facilitator terhadap kemampuan menyimpulkan isi berita yang dibacakan dalam beberapa kalimat lebih besar dibandingkan 
rata-rata hasil tes siswa kelas kontrol yang tidak menggunakan model pembelajaran student facilitator terhadap kemampuan menyimpulkan isi berita yang dibacakan dalam beberapa kalimat. Terdapat pengaruh yang signifikan antara model pembelajaran student facilitator terhadap hasil menyimpulkan isi berita yang dibacakan dalam beberapa kalimat siswa kelas III SDN 93 Palembang yang ditunjukan dengan hasil $\mathrm{t}_{\text {tabel }}<\mathrm{t}_{\text {hitung }}=2,00<7,03$.

Dengan hasil penelitian diperoleh tes hasil belajar yang menggunakan model pembelajaran student facilitator terhadap kemampuan menyimpulkan isi berita yang dibacakan dalam beberapa kalimat lebih baik dari pada tes hasil belajar yang tidak menggunakan model pembelajaran terhadap kemampuan menyimpulkan isi berita yang dibacakan dalam beberapa kalimat. Kondisi pembelajaran pada saat menggunakan model pembelajaran student facilitator, siswa sangat aktif untuk mengemukakan ide atau pendapatnya terhadap pembelajaran menyimpulkan isi berita yang diberikan guru.
Sehubungan telah dilakukan pembelajaran yang menggunakan suatu model pembelajaran student facilitator terhadap kemampuan menyimpulkan isi berita dalam penelitian ini, maka ada beberapa saran yang akan peneliti sampaikan yaitu dengan model pembelajaran student facilitator dapat digunakan sebagai salah satu alternatif model pembelajaran yang dapat digunakan dalam berbagai macam pembelajaran teruta ma dalam pembelajaran bahasa Indonesia dengan upaya untuk meningkatkan kemampuan siswa dalam pembelajaran materi menulis kesimpulan isi berita sehingga hasil pembelajaran dapat lebih meningkat dan aktif dalam proses pembelajaran.

Bahkan dengan adanya fasilitas yang memadai khususnya buku-buku yang bersangkutan dengan pembelajaran bahasa Indonesia seperti yang ada di materi tentang berita, selain itu juga untuk peneliti lanjut, khususnya mahasiswa Program Studi Pendidikan Bahasa danSastra Indonesia, hendaknya melakukan penelitian pendidikan lebih luas lagi mengenai model pembelajaran yang ada, sehingga informasi yang diperoleh dapat dipakai sebagai 
perbandingan dan acuan dalam proses belajar mengajar disekolah untuk meningkatkan hasil belajar yang lebih baik.

\section{DAFTAR PUSTAKA}

Arikunto, Suharsimi. 2013. Prosedur Penelitian Satuan Pendekatan Praktek. Jakarta: Rineka Cipta.

Chaer, Abdul. 2010. Bahasa Jurnalistik. Jakarta: Rieneka Cipta.

Departemen Pendidikan dan Kebudayaan. 2008. Kamus Besar Bahasa Indonesia. Jakarta: Balai Pustaka.

Huda, Miftahul. 2014. Model-Model Pengajaran dan Pembelajaran. Yogyakarta: Pustaka Belajar.

Kurnia. 2012. Bahan Ajar Linguistik Umum. Tidak diterbitkan. FKIP: Universitas PGRI Palembang.

Latuconsina, Chandra. 2014. Keterampilan Pers dan Jurnalistik. Tidak diterbitkan. FKIP: Universitas PGRI Palembang.

Nurgiyantoro, Burhan. 2012. Penilaian Pembelajaran Bahasa Berbasis Kompetensi. Yogyakarta: BPFE.

Rusman. 2012. Model-Model Pembelajaran Mengembangkan Profesionalisme Guru. Jakarta: Rajawali Pers.

Sugiyono. 2012. Metode Penelitian Kuantitatif Kualitatif dan $R \& D$. Bandung. Alfabeta.

Sudjana. 2013. Metode Statistika. Badung: Tarsito.

Sutriyani. 2013. Pengaruh Model Pembelajaran
Facilitator and Explaining Terhadap Kemampuan Siswa Kelas V SD Negeri 122 Palembang Menentukan Isi Pengumuman. Skripsi Tidak Diterbitkan. Palembang: Universitas PGRI Palembang. Tarigan, Henry Guntur. 2008. Menyimak Sebagai Suatu Keterampilan Berbahasa. Bandung: Angkasa

Trianto. 2013. Mendisain Model Pembelajaran InovatifProgresif. Jakarta: Kencana Prenada Media Group. 